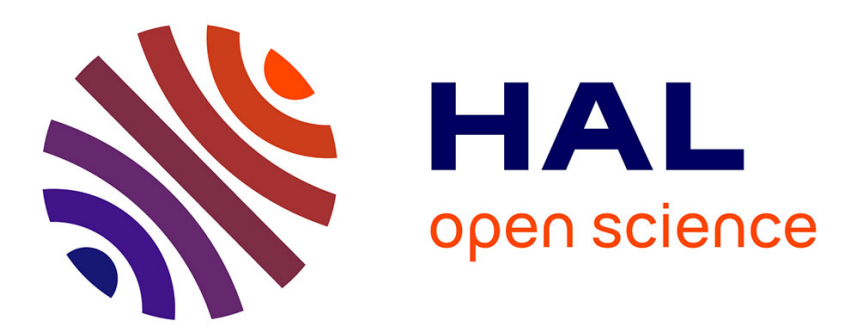

\title{
Downregulation of Notch signaling by $\gamma$-secretase inhibition can abrogate chemotherapy-induced apoptosis in T-ALL cell lines
}

Shuangyou Liu, Stephen Breit, Sven Danckwardt, Martina U. Muckenthaler, Andreas E. Kulozik

\section{To cite this version:}

Shuangyou Liu, Stephen Breit, Sven Danckwardt, Martina U. Muckenthaler, Andreas E. Kulozik. Downregulation of Notch signaling by $\gamma$-secretase inhibition can abrogate chemotherapy-induced apoptosis in T-ALL cell lines. Annals of Hematology, 2008, 88 (7), pp.613-621. 10.1007/s00277-008-0646x . hal-00535008

\author{
HAL Id: hal-00535008 \\ https://hal.science/hal-00535008
}

Submitted on 11 Nov 2010

HAL is a multi-disciplinary open access archive for the deposit and dissemination of scientific research documents, whether they are published or not. The documents may come from teaching and research institutions in France or abroad, or from public or private research centers.
L'archive ouverte pluridisciplinaire HAL, est destinée au dépôt et à la diffusion de documents scientifiques de niveau recherche, publiés ou non, émanant des établissements d'enseignement et de recherche français ou étrangers, des laboratoires publics ou privés. 


\title{
Downregulation of Notch signaling by $\gamma$-secretase inhibition can abrogate chemotherapy-induced apoptosis in T-ALL cell lines
}

\author{
Shuangyou Liu • Stephen Breit • Sven Danckwardt • \\ Martina U. Muckenthaler • Andreas E. Kulozik
}

Received: 18 September 2008 / Accepted: 11 November 2008 / Published online: 5 December 2008

(C) Springer-Verlag 2008

\begin{abstract}
Activation of Notch1 signaling plays an important role in the pathogenesis of precursor T-cell lymphoblastic leukemia (T-ALL). The Notch1 receptor is cleaved and activated via the $\gamma$-secretase complex. Downregulation of Notch1 signaling by $\gamma$-secretase inhibitors (GSIs) thus represents a potential novel therapeutic approach. In this study, we analyzed the response of four T-ALL cell lines to compound E, a potent $\gamma$-secretase inhibitor, and to the combination of compound $\mathrm{E}$ with vincristine, daunorubicin, L-asparaginase (L-ASP), and dexamethasone (DEX). We identified two distinct types of responses: In type 1 cell lines, represented by TALL1 and HSB2, GSI-induced apoptosis followed cell cycle arrest and enhanced the induction of apoptosis caused by DEX and L-ASP. In type 2 cell lines, represented by CEM and Jurkat J6, GSI caused neither cell cycle block nor cell death. Notably, the combination of GSI with chemotherapy-induced resistance by decreasing apoptosis. In type 2 cells, GSI induced the upregulation of Bcl-xl mRNA and protein, which was thus identified as a candidate mechanism for the inhibition of apoptosis. In conclusion, the data presented here caution against clinical use of a combination treatment of GSI and chemotherapy in T-ALL.
\end{abstract}

Keywords Acute lymphoblastic leukemia · Notch . Apoptosis $\cdot$ Chemotherapy

S. Liu $\cdot$ S. Breit $\cdot$ S. Danckwardt $\cdot$ M. U. Muckenthaler $\cdot$

A. E. Kulozik $(\square)$

Department of Pediatric Oncology, Hematology and Immunology, University of Heidelberg,

Im Neuenheimer Feld 430,

69120 Heidelberg, Germany

e-mail: andreas.kulozik@med.uni-heidelberg.de

\section{Introduction}

Precursor T-cell lymphoblastic leukemia (T-ALL) is an aggressive malignant disease induced by malignant transformation of T-cell precursors, which accounts for $10 \%$ to $15 \%$ of all leukemias in children and adolescents [1]. The outcome of treatment has improved dramatically reaching an event-free survival rate of up to $80 \%$ [2]. Despite this significant progress in the success of treatment, patients with relapsed disease continue to have a particularly poor prognosis [3]. Furthermore, surviving patients often experience significant toxicity [4]. Therefore, it is important to establish risk adapted treatment strategies that improve survival in high risk patients and decrease toxicity in standard risk patients.

A series of recent studies have demonstrated that activation of the Notch1 signaling pathway can induce TALL in mice and humans [5-7]. The Notch1 gene encodes a single pass heterodimeric transmembrane receptor, which has an essential function in the development of normal $\mathrm{T}$ cells [8]. When expressed in hematopoietic stem cells of mice, constitutively activated forms of Notch1 are potent inducers of T-ALL [6]. Furthermore, $50 \%$ to $60 \%$ of human T-ALL cell lines and primary patient samples were shown to harbor activating mutations in the Notch1 gene that result in aberrant Notch1 signaling [9, 10].

The activation of Notch1 signaling is triggered either by the Notch1 receptor-ligand interaction or by mutations of the Notch1 gene. Ligand binding initiates two successive proteolytic cleavages, mediated first by a disintegrin and metalloprotease (S2 cleavage) and second by a $\gamma$-secretase complex (S3 cleavage). The final cleavage releases the intracellular domain of Notch1 (ICN1) from the cell membrane, which translocates into the nucleus and interacts with CBF1/RBP-JK/Suppressor of Hairless/ 
LAG-1 transcription factor to activate downstream target genes such as Deltex1, Hes1, and c-Myc [1, 8, 11-13].

Considering the essential role of aberrant Notch1 signaling in the pathogenesis of T-ALL, blocking of the Notch1 activity by small molecule inhibition of $\gamma$-secretase represents a potentially attractive strategy of targeted therapy for T-ALL $[1,9,14-16]$. It has been reported that the treatment with $\gamma$-secretase inhibitors (GSIs) induces cell growth arrest and cell apoptosis in several different T-ALL cell lines by decreasing Notch1 signal transduction [7, 9, 16]. Consequently, clinical trials with GSI in T-ALL have been initiated [17].

In principle, blocking Notch1 signaling by GSI might be synergistic with chemotherapy for the treatment of T-ALL and we thus set out to test this strategy in T-ALL cell lines. To our surprise, however, the effect of GSI treatment and downregulation of Notch1 activity was variable and even resulted in the induction of chemotherapy resistance in two of the four cell lines tested. These findings indicate an unexpected and complicated interrelationship between the effects of chemotherapy and Notch1 pathway inhibition. These data thus caution against the clinical use of Notch1 pathway inhibition until this interaction is understood in more detail.

\section{Materials and methods}

\section{Cell lines and culture}

Human leukemia cell lines of T-ALL origin (TALL1, HSB2, Jurkat J6, and CEM) were obtained either from the American Type Culture Collection (LGC Promochem, Wesel, Germany) or from the German Collection of Microorganisms and Cell Cultures (Braunschweig, Germany). All cell lines were cultured in RPMI 1640 (Invitrogen, Germany) supplemented with $10 \%$ fetal calf serum, 2 mM L-glutamine, $100 \mathrm{U} / \mathrm{ml}$ penicillin, and $100 \mu \mathrm{g} / \mathrm{ml}$ streptomycin at $37^{\circ} \mathrm{C}$ and $5 \% \mathrm{CO}_{2}$.

\section{$\gamma$-Secretase inhibitor treatment}

Compound E (Merck-Calbiochem, Germany), a potent $\gamma$ secretase inhibitor, was used to block Notch1-mediated signal transduction in T-ALL cell lines. Cells in logarithmic growth were seeded at densities of either $1 \times 10^{5}$ cells $/ \mathrm{ml}$ (CEM and Jurkat J6), $2 \times 10^{5}$ cells/ml (HSB2), or $4 \times$ $10^{5}$ cells/ml (TALL1) according to different growth rates and cultured in the presence of different concentrations of compound $\mathrm{E}(1,2,5$, and $10 \mu \mathrm{M})$ for up to 7 days. Mocktreated cultures were exposed to vehicle (dimethyl sulfoxide, DMSO) only at the same concentration as in compound E containing cultures $(0.1 \%)$. At various time points after treatment onset, the effects of GSI on the expression of
Notch1 target genes, cell cycle distribution, and apoptosis were analyzed.

Treatment with chemotherapy

The following four drugs (Sigma-Aldrich, Germany) were used in the indicated concentrations and incubation periods: daunorubicin (DNR; $0.5 \mu \mathrm{M}$ ) and vincristine (VCR; $1 \mu \mathrm{M}$ ) for $24 \mathrm{~h}$ and dexamethasone (DEX; $10 \mu \mathrm{M})$ and L-asparaginase (L-ASP; $1 \mathrm{U} / \mathrm{ml}$ ) for $48 \mathrm{~h}$. To evaluate the effects of inhibited Notch1 signaling combined with chemotherapy, cells were first incubated either with different concentrations of compound $\mathrm{E}$ (CE) or vehicle control (DMSO) for 3 (HSB2) or 4 (TALL1, Jurkat J6, and CEM) days. Subsequently, these CE pretreated cells were pelleted to remove the old medium containing CE or DMSO and resuspended in fresh standard medium. After reseeding at a density of $1 \times 10^{6}$ cells $/ \mathrm{ml}$ in 24 well plates (Nunc, Germany), the chemotherapy drugs were added. Cell apoptosis rates were analyzed after 24 (VCR and DNR) or $48 \mathrm{~h}$ (L-ASP and DEX).

\section{Flow cytometry}

A Coulter EPICS XL-MCL Flow Cytometer (Beckman Coulter Inc., USA) with $488 \mathrm{~nm}$ excitation was used to measure cell cycle distribution and cell apoptosis rates. Data analyses were conducted by the package XL SYSTEM II'M software. Annexin V-FITC apoptosis detection kits (BD Biosciences Pharmingen) were used to assay cell apoptosis according to the manufacturer's instructions. The total apoptosis rates were calculated as the sum of all Annexin$\mathrm{V}$ positive and propidium iodide (PI) positive cells. For cell cycle measurement, cells were first fixed in ice-cold $80 \%$ ethanol for at least overnight, then washed with phosphate buffered saline and stained in the PI/RNaseA staining buffer (BD Biosciences) containing $10 \mu \mathrm{g} / \mathrm{ml}$ propidium iodide.

\section{Quantitative real-time RT-PCR}

Total cellular RNA was extracted with the TRIzol reagent (Molecular Research Center, Inc.). Single-stranded cDNA was generated from $1 \mu \mathrm{g}$ of total RNA using MMLV RNaseH-Reverse Transcriptase (MBI Fermentas) and oligo$\mathrm{dT}$ primers. The assessment of relative mRNA gene expression was performed by real-time reverse transcriptase polymerase chain reaction (RT-PCR) with the LightCycler system (Roche Diagnostics, Germany); melting curves of PCR products were performed for quality control. Glyceraldehyde 3-phosphate dehydrogenase (GAPDH) mRNA was used for normalization. The mRNA expression level was the mean value of three independent experiments. The following primers were used: Deltexl forward 5'AAGAAGTTCACCGCAAGAGGATT-3' and Deltex 1 
reverse 5'-CTAGGTAGCTAGCGTCCGGGTAG-3'; $B c l$-xl forward 5'-AAGCGTAGACAAGGAGATGC and $B c l$-xl reverse 5'-GGAGGGTAGAGTGGATGGT; and GAPDH forward 5'-TGAGCTTGACAAAGTGGTCG-3' and GAPDH reverse 5'-GGCTCTCCAGAACATCATCC-3'.

\section{Western blot analysis}

Whole-cell protein extracts were isolated with radioimmunoprecipitation assay lysis buffer and sodium dodecyl sulfate (SDS) sample buffer. Equal amounts of proteins (30-50 $\mu \mathrm{g} /$ lane) were separated in $6-10 \%$ SDS-polyacrylamide gel electrophoresis. After electrophoresis, proteins were transferred to polyvinylidene fluoride membranes. The membranes were blocked by $5 \%$ nonfat milk for $1 \mathrm{~h}$ at room temperature and then incubated with primary antibodies Notch1 (sc-6014, 1:2,000), Jagged1 (sc-6011, 1:250), Delta (sc-8155, 1:250, recognizing both Delta1 and Delta 4) from Santa Cruz, and antibody Bcl-xl from Cell Signaling (\#2762, 1:1,000) at $4^{\circ} \mathrm{C}$ overnight. The corresponding horseradish peroxidase-conjugated secondary antibodies were incubated for $1-2 \mathrm{~h}$ at room temperature, and protein bands were developed by chemiluminesence (Amersham Pharmacia Biotech).

\section{Notch1 gene sequencing}

Total DNA was extracted using QIAamp DNA mini kit (Qiagen). Sequencing of PCR-amplified DNA fragments of Notch 1 gene was identified with BigDye Terminator v3.1 Cycle Sequencing Kit in the ABI PRISM 3100 Genetic Analyzer (Applied Biosystems).

\section{Statistics}

Results were expressed as means \pm standard error. Student's $t$ test was performed for estimation of statistical significance. Significant changes within the $95 \%$ confidence interval $(P<0.05)$ are marked by an asterisk.

\section{Microarray analysis}

Microarray analyses were performed as described previously [18] by using the following detailed protocol.

\section{Preparation and postprocessing of spotted oligonucleotide} microarrays Synthetic 50-mer oligonucleotides ("Human 30 k Oligo Sets A and B"; consisting of 19,970 oligonucleotides representing human genes and transcripts plus controls) were purchased from MWG-Biotech AG (Ebersberg, Germany) and dissolved in $3 \times \mathrm{SSC} / 1.5 \mathrm{M}$ Betaine at $5 \mu \mathrm{M}$. DNA spotting was performed in duplicates on Gamma Amino Propyl Silane (GAPS) coated slides (UltraGAPS II; Corning, Acton, MA, USA) using an OmniGrid Microarrayer (GeneMachines, San Carlos, CA, USA) equipped with Stealth SMP3 Micro Spotting Pins (Telechem, Sunnyvale, CA, USA). Spot diameters were $110 \mu \mathrm{m}$ and center-to-center spacing $150 \mu \mathrm{m}$. DNA adhesion to the glass surface was accomplished by $1 \mathrm{~h}$ incubation at $70^{\circ} \mathrm{C}$, followed by UV irradiation $(1 \times 120 \mathrm{~mJ} /$ $\mathrm{cm}^{2}$ at $254 \mathrm{~nm}$ ) in a Stratalinker Model $2400 \mathrm{UV}$ illuminator (Stratagene, La Jolla, CA, USA). Just prior to hybridization, slides were mounted in an automated hybridization station (Lucidea Slide Processor; GE Healthcare, Freiburg, Germany) and incubated for $60 \mathrm{~min}$ at $42^{\circ} \mathrm{C}$ in a prehybridization buffer $[5 \times \mathrm{SSC} / 0.1 \% \operatorname{SDS}(w / v) / 0.1 \%$ bovine serum albumin].

Target preparation for spotted oligonucleotide arrays Fluorescently labeled antisense cDNA was prepared from $1 \mu \mathrm{g}$ of total RNA from DMSO-treated (controls) and GSItreated (samples) cells using a T7-polymerase-based transcriptome amplification method (TAcKLE procedure). Briefly, for amplification and labeling using the TAcKLE protocol, $1 \mu \mathrm{g}$ of total RNA was mixed with $100 \mathrm{ng}$ (dT)-T7 primer and employed in the first- and secondstrand cDNA synthesis. Subsequently, double-stranded cDNA was purified by extraction with phenol/chloroform/ isoamylalcohol, followed by ethanol precipitation. The cDNA was dissolved in nuclease-free water and employed in an in vitro transcription reaction using a RiboMAX Large Scale RNA Production System T7 (Promega, Madison, WI, USA) according to the manufacturer's recommendations, but in $40 \mu \mathrm{l}$ reaction volume and at $37^{\circ} \mathrm{C}$ for $16 \mathrm{~h}$ (over night). Following purification on RNeasy Mini filters (Qiagen, Hilden, Germany) and ethanol precipitation, aRNA was dissolved in nuclease-free water. Second-round RT was performed on $1 \mu \mathrm{g}$ aRNA with $0.5 \mu \mathrm{g}$ random hexamer primer (Roche Diagnostics, Mannheim, Germany). Subsequently, cDNA labeling by Klenow fragment was performed using the BioPrime DNA Labeling System (Invitrogen, Karlsruhe, Germany) in a final volume of $50 \mu \mathrm{l}$. DNA polymerization was carried out at $37^{\circ} \mathrm{C}$ for $16 \mathrm{~h}$ (over night).

Microarray hybridization Following completion of the labeling reactions, corresponding cDNA samples were combined. For blocking of repetitive sequence elements, $10 \mu \mathrm{g} \mathrm{C}$ ot-1 DNA (Roche Diagnostics), $5 \mu \mathrm{g}$ poly(A) DNA (Sigma-Aldrich, Munich, Germany), and $20 \mu \mathrm{g}$ yeast tRNA (Sigma-Aldrich) were added. Subsequently, the dye-labeled cDNA samples were dried to completeness for $30 \mathrm{~min}$ in a low vacuum SpeedVac system (Eppendorf, Hamburg, Germany), resuspended in $200 \mu$ l hybridization buffer $[5 \times \mathrm{SSC} / 30 \%$ formamide $/ 0.1 \%$ SDS $(w / v)]$, agitated for $10 \mathrm{~min}$ at $95^{\circ} \mathrm{C}$ on a thermo mixer, and then applied to 
prehybridized and preheated $\left(42^{\circ} \mathrm{C}\right)$ microarrays mounted in an automated hybridization station (Lucidea Slide Processor; GE Healthcare). Hybridizations were performed for $23 \mathrm{~h}$ at $42^{\circ} \mathrm{C}$ with gentle agitation. Thereafter, the arrays were automatically washed at room temperature with (a) $1 \times$ $\mathrm{SSC} / 0.2 \% \mathrm{SDS}(w / v)$ for $2 \times 2 \mathrm{~min}$, (b) $0.1 \times \mathrm{SSC} / 0.2 \% \mathrm{SDS}$ $(w / v)$ for $2 \times 5 \mathrm{~min}$, and (c) $0.1 \times \mathrm{SSC}$ for $5 \mathrm{~min}$. Immediately after the completion of the final washing step, the arrays were rinsed with isopropanol and dried completely.

Image analysis and data processing Hybridized microarrays were scanned at a resolution of $10 \mu \mathrm{m}$ on a GenePix 4000 B microarray scanner (Axon Instruments, Foster City, CA, USA), using fixed laser power and variable photo multiplier tube voltage of the two channels to obtain maximal signal intensities with $<0.1 \%$ probe saturation and a count ratio of 0.9-1.1 (Cy5/Cy3). Subsequent image analysis was performed with the corresponding software GenePix Pro 4.1 (Axon Instruments). Spots not recognized by the software and artifact-associated spots were excluded from further considerations. The GeneSpring 6.1 software package (Silicon Genetics, Redwood City, CA, USA) was used for normalization, background correction, and scaling of all genes and arrays. Using the 50\% percentile of each chip's intensity range, expression values were normalized across the sample set by scaling the average of the intensities of all genes to constant target intensity. Each gene's measured intensity was divided by its control channel value (negative control; GSI-treated against DMSO-treated cells); intensity values below 50 were excluded ("flagged"). The bottom $10 \%$ percentile was used for background subtraction (intensity approximately 2 standard deviations (SD) above background). A Student's $t$ test on the normalized relative expression ratios was used to identify significant genes differentially expressed with a minimum factor of difference of $>2$-fold, within a $95 \%$ confidence interval $(P<0.05)$.

\section{Results}

Inhibition of Notch1 signaling

We first characterized the expression of Notch1 in the four T-ALL cell lines (CEM, Jurkat J6, HSB2, and TALL1) used here as model systems. The analysis of protein expression (Fig. 1a) showed Notch1 in all cell lines. In CEM and HSB2, the abundance of Notch1 was considerably higher than in Jurkat J6 and TALL1 (compare lanes 1 and 3 with lanes 2 and 4). Increased Notch1 expression correlated with an activating Notch1 mutation within the heterodimerization domain (a 12-amino acid PRLPHNSSFHFL insertion at position 1595) in CEM (data not shown) and increased expression of the Notch1 ligand Jagged1 in HSB2 (Fig. 1a, lane 3), respectively.

Inhibition of $\gamma$-secretase by different concentrations of compound $\mathrm{E}(1,2,5$, and $10 \mu \mathrm{M})$ resulted in significant downregulation to less than $20 \%$ of Deltex 1 mRNA abundance, indicating that the Notch1 signaling pathway was efficiently blocked by compound $\mathrm{E}$ treatment in all four cell lines (Fig. 1b). These concentrations were therefore used subsequently to effectively inhibit the Notch1 pathway.

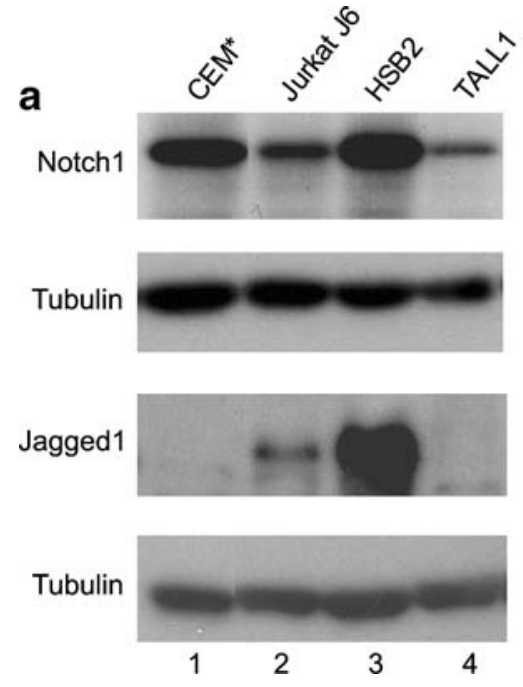

Fig. 1 Notch 1 is expressed in model T-ALL cell lines and can be blocked by the $\gamma$-secretase inhibitor compound E. a Western blot analysis of nontreated T-ALL cell lines. Equal amounts of total protein $(30 \mu \mathrm{g})$ were loaded. The indicated antibodies were used to detect the corresponding proteins. Tubulin was used as a loading control. *Cell b

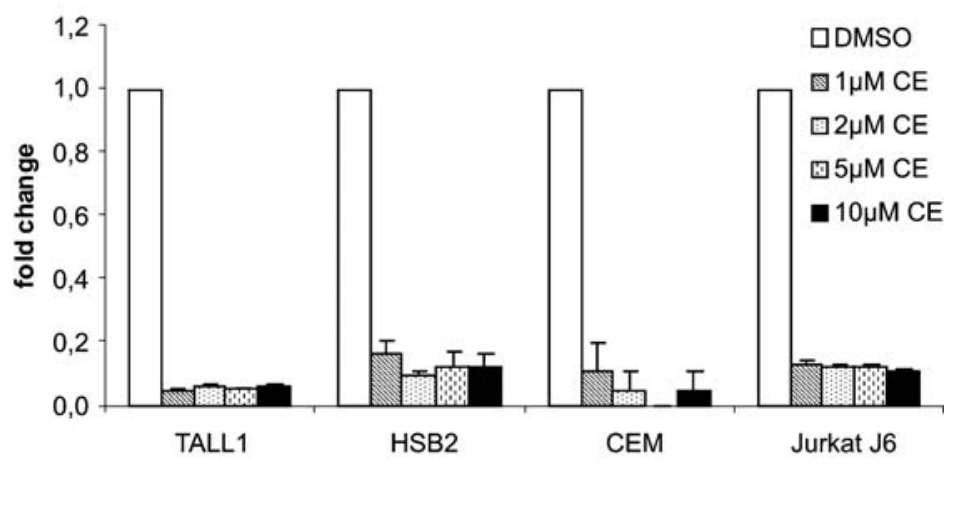

line with an activating mutation of the NOTCH1 heterodimerization domain. b Quantitative RT-PCR analysis of Deltex 1 mRNA following treatment with different concentrations of compound $\mathrm{E}$ or DMSO control. GAPDH mRNA abundance was used for normalization. The mean values $( \pm \mathrm{SD})$ were calculated from three independent experiments 
Effects of GSI treatment alone on cell cycle distribution and cell apoptosis

To monitor the effects of continuous GSI treatment on cell proliferation, the four T-ALL cell lines were treated with $\mathrm{CE}$ for 3 (HSB2) or 4 days (TALL1, CEM, and Jurkat J6) and cell cycle profiles were analyzed by flow cytometry. Inhibition of Notch1 signaling in TALL1 cells resulted in G0/G1 cell cycle arrest, indicated by a reduction of cells in $\mathrm{S}$ (from $26.8 \pm 1.4 \%$ to $18.4 \pm 2.5 \%$ ) and $\mathrm{G} 2 / \mathrm{M}$ phases (from $17.4 \pm 1.5 \%$ to $12.9 \pm$ $1.5 \%$ ) and an accumulation of cells in G0/G1 (from 53.1 $1.0 \%$ to $66.2 \pm 2.7 \%$; Fig. 2 a). HSB2 cells displayed a similar a

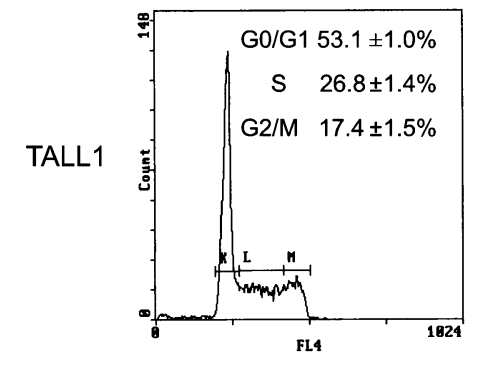

Control

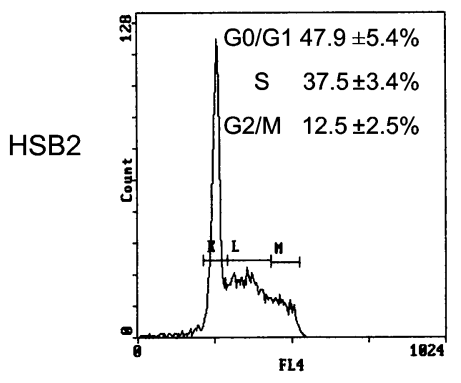

b
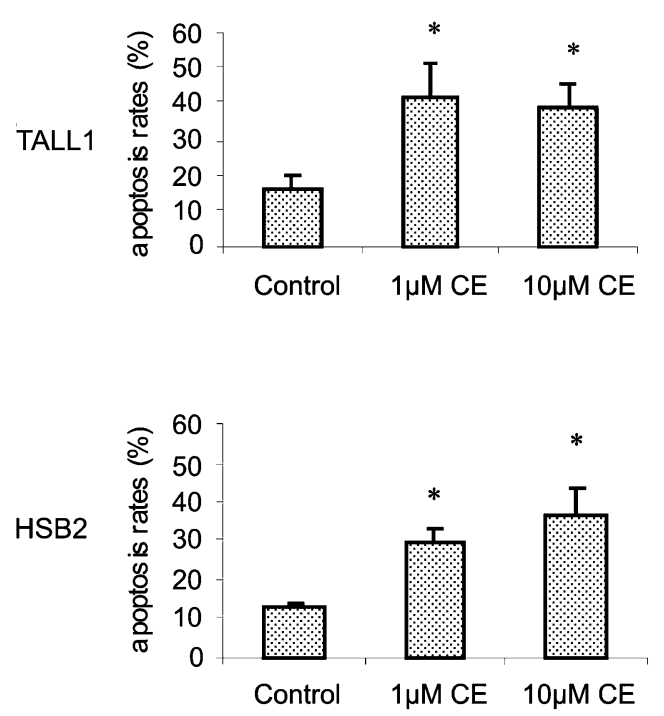
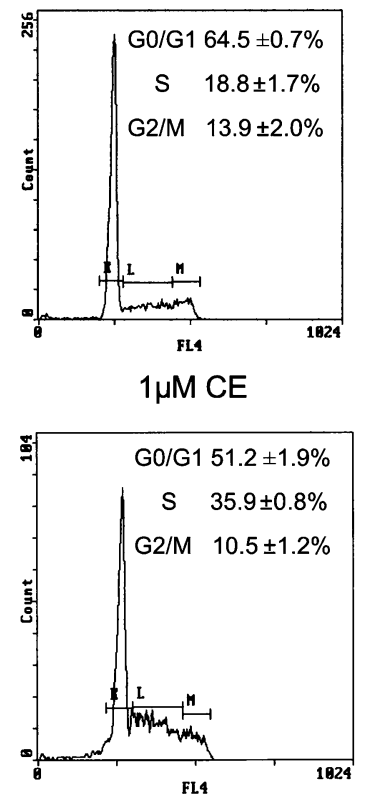

FL4
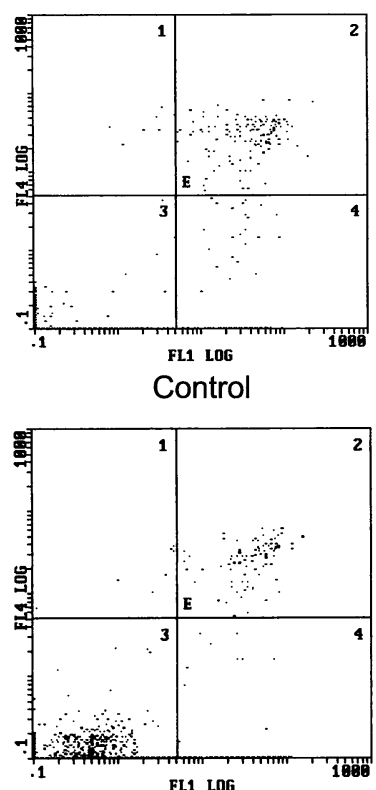
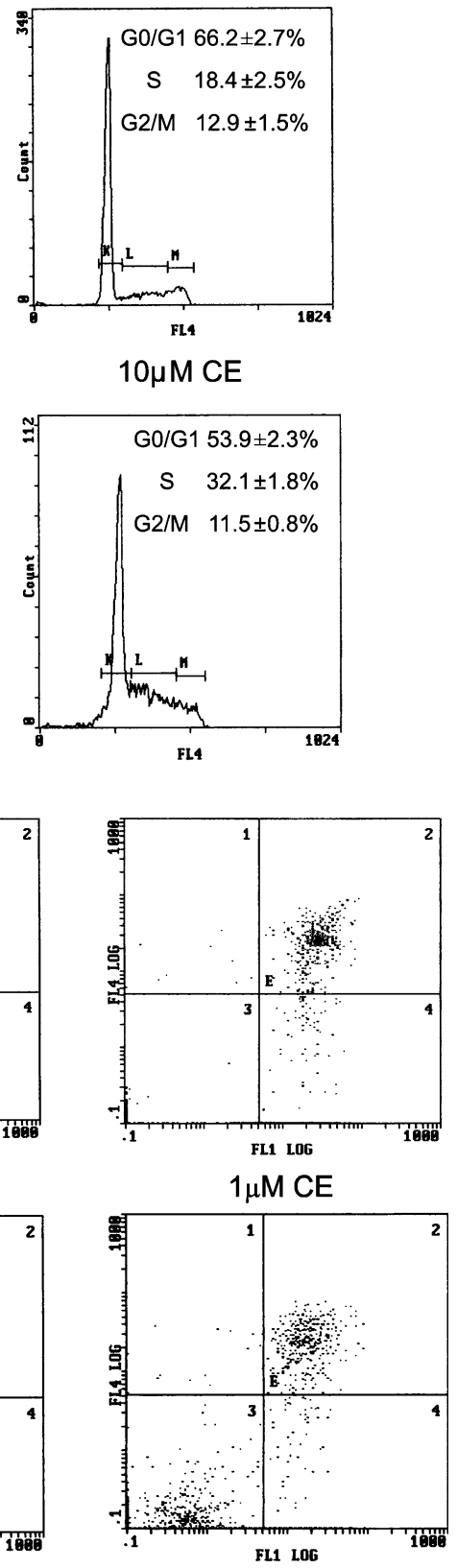

Fl1 Log
Fig. $2 \gamma$-Secretase inhibition by compound $\mathrm{E}$ treatment results in G0/ G1 cell cycle block and apoptosis in TALL1 and HSB2 cell lines. a Representative DNA histograms and mean percentages of cells in different phases of the cell cycle from three independent experiments. Cells were obtained after 4 days (TALL1) or 3 days (HSB2) of incubation with CE or DMSO as a control. The proportion of cells in $\mathrm{G} 0 / \mathrm{G} 1, \mathrm{~S}$, and $\mathrm{G} 2 / \mathrm{M}$ phases of the cell cycle are inserted in the fluorescence activated cell sorting (FACS) diagrams. b Apoptosis rates were measured by flow cytometry following Annexin V/PI staining following treatment of the cells with either DMSO only or with 1 and $10 \mu \mathrm{M}$ compound $\mathrm{E}(C E)$. The FACS plots shown on the right show representative experiments with the DMSO control and $1 \mu \mathrm{M}$ compound E. Quadrant 2 of the FACS plot contains the late apoptotic, $\mathrm{PI}$, and annexin V staining cells and quadrant 4 contains the early apoptotic cells that stain with annexin V only. Cells were measured on day 7 (TALL1) or 5 (HSB2) after incubation with CE or DMSO control. The mean values $( \pm \mathrm{SD})$ were calculated from at least four independent experiments. ${ }^{*} P<0.05$ 
but less pronounced effect on the cell cycle. In this cell line, GSI treatment resulted in a marginal decrease of cells in $\mathrm{S}$ (from $37.5 \pm 3.4 \%$ to $32.1 \pm 1.8 \%$ ) and $\mathrm{G} 2 / \mathrm{M}$ phases (from $12.5 \pm 2.5 \%$ to $10.5 \pm 1.2 \%$ ) and an increase of cells in $\mathrm{G} 0 / \mathrm{G} 1$ (from $47.9 \pm 5.4 \%$ to $53.9 \pm 2.3 \%$; Fig. 2 b). In contrast, in the CEM and Jurkat J6, inhibition of Notch1 signaling did not result in changes of the proportion of cells in different phases of the cell cycle (data not shown).

We next analyzed if the effects of GSI treatment on cell cycle progression in TALL1 and HSB2 lines had an effect on cell viability and apoptosis. We thus monitored annexin $\mathrm{V}$ and PI staining on day 5 (HSB2) or 7 (TALL1) of GSI treatment. In both cell lines, GSI treatment induced apoptosis with a 2.3- to 2.9-fold increase of annexin V staining cells when compared to DMSO-treated controls (Fig. 2b). The quantitative effect of GSI treatment with respect to the induction of apoptosis was similar in these two cell lines, which suggests that there may be no direct relationship between the GSI-induced effects on the cell cycle and apoptosis in these cell lines. An analysis of cell viability and apoptosis of the CEM and Jurkat J6 cells demonstrated that $C E$ treatment at all four concentrations had no effect, even after incubation for 7 days (not shown). These data indicate that the viability of these cell lines is independent of Notch activity and that these cell lines are resistant to the GSI effects on cell cycle progression and apoptosis.

Effects of GSI combined with chemotherapy drugs on apoptosis

It has been proposed that the inhibition of Notch1 signaling by GSI may be synergistic and clinically beneficial in combination with standard chemotherapy protocols of TALL [1]. In order to assess the effect of such a combination
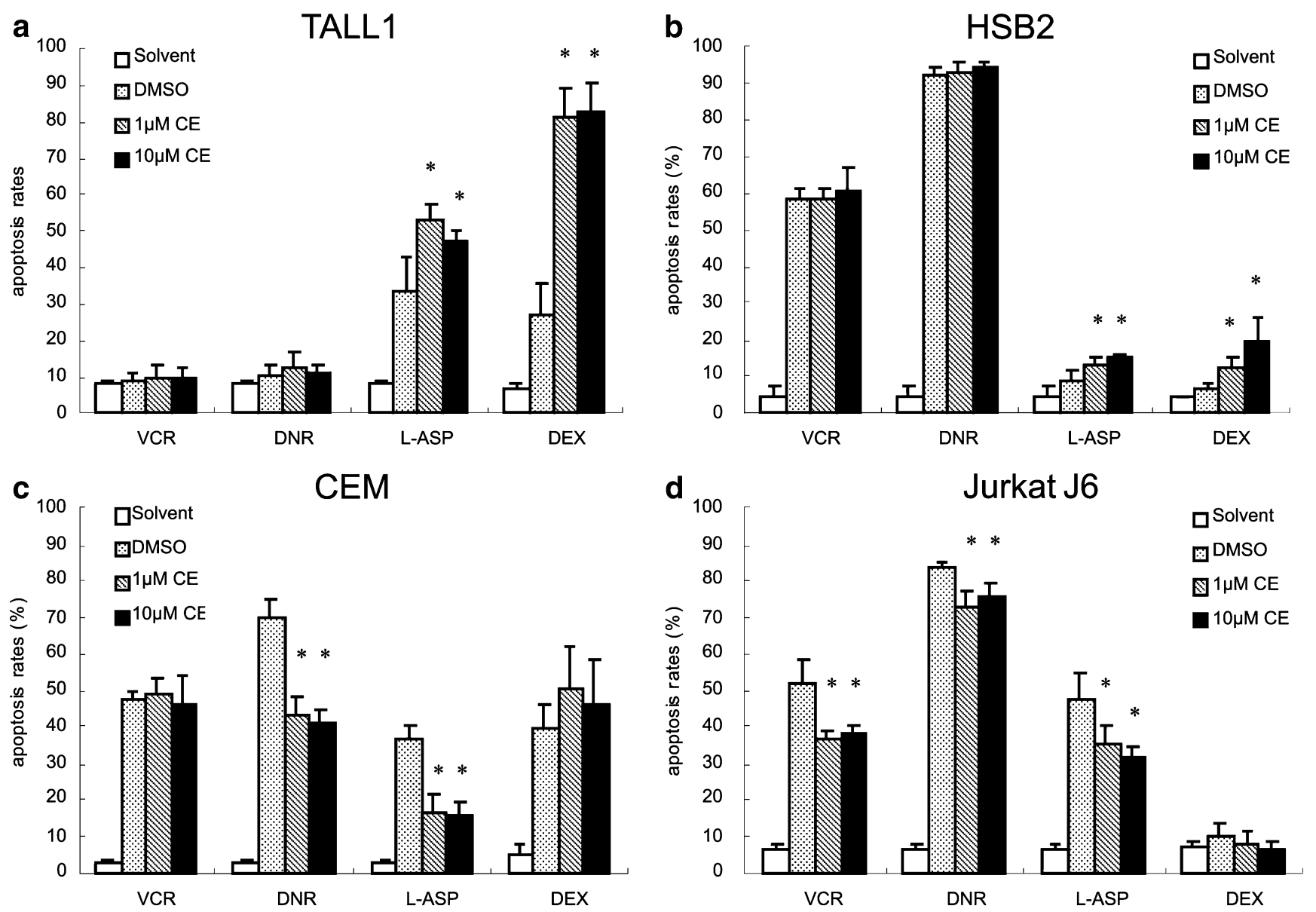

Fig. 3 Apoptosis rates induced by combination treatment of compound $\mathrm{E}$ with chemotherapy. VCR vincristine, DNR daunorubicin, $L-A S P$ Lasparaginase, Dex dexamethasone. Cells were pretreated with different concentrations of CE or DMSO control for 3 (HSB2) or 4 days (CEM, TALL1, Jurkat J6). Subsequently, the cells were incubated with the indicated drugs for 24 or $48 \mathrm{~h}$. Apoptosis was measured by flow

cytometry after Annexin V/PI staining. Solvent indicates that cells have not been pretreated with $\mathrm{CE}$ and but were treated with the solvent of the corresponding chemotherapy agents. The mean values $( \pm \mathrm{SD})$ were calculated from three to five independent experiments. $* P<0.05$ compared to DMSO control 
strategy, we either treated the cell lines with VCR, DNR, LASP, or DEX, which are known to be effective clinically in T-ALL, or pretreated with different concentrations of CE for 3 (HSB2) or 4 (TALL1, CEM and Jurkat J6) days before the cells were exposed to chemotherapy.

In the GSI-sensitive cell lines TALL1 and HSB2 (Fig. 2), the apoptotic effects induced by L-ASP and DEX were markedly augmented when cells were pretreated with CE. However, no increased rates of apoptosis were detectable when the cells were exposed to either VCR or DNR (Fig. 3a,b). In the GSI-resistant cell lines, we did not observe an effect of combining GSI treatment with VCR and DEX in CEM or with DEX in Jurkat J6. To our surprise, the apoptotic effects of DNR and L-ASP (CEM) or VCR, DNR, and L-ASP (Jurkat J6) were significantly antagonized by GSI (Fig. 3c,d). These data demonstrate that the GSI pretreatment markedly decreased the susceptibility of these cells to chemotherapy-induced cell death.

Taken together, these data indicate the presence of two types of effects upon GSI and combination treatment of GSI with chemotherapy. In type 1 cells, represented by TALL1 and HSB2, GSI alone results in the induction of apoptosis, which can be additive or synergistic with chemotherapy. This type of response is similar to that described previously [38]. However, in type 2 cells, represented by CEM and J6, GSI alone is not effective and may even antagonize the effect of chemotherapy.

GSI treatment can upregulate the expression of the antiapoptotic gene Bcl-xl

We next explored the mechanism of the surprising antagonistic effect of GSI on chemotherapy in type 2 cells by comparing mRNA expression profiles of GSI-treated

a

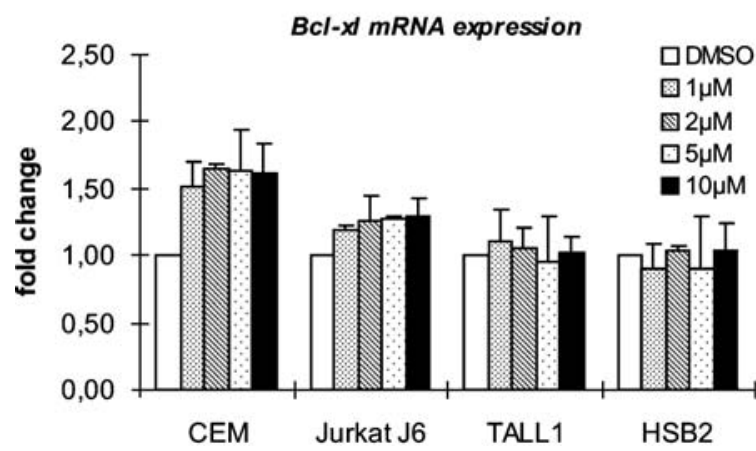

Fig. 4 Compound E upregulates the expression of BCL-xl in CEM and Jurkat J6 cells. Cells were harvested after incubation with either compound $\mathrm{E}$ or DMSO. a Bcl-xl mRNA abundance measured by real time quantitative RT-PCR. DMSO controls were set as 1.0. The mean values and DMSO-treated type1 HSB2 and type 2 CEM cells using microarray analysis. Of a total of 19,970 oligonucleotides/genes present on the spotted oligonucleotide microarray, 5,646 genes (100\%) were expressed at a significant level above background in both cell lines. Following GSI treatment, the expression levels of 612 genes $(10.8 \%)$ in HSB2 cells and of 603 genes $(10.7 \%)$ in CEM cells differed from those in the respective control samples by a factor of $>2.0$-fold. In the next step of analysis, we filtered those genes that were equally regulated in both cell lines, which generated a list of 168 genes (3.0\%) that were specifically deregulated in the type 2 CEM cells. Among these genes, we identified the antiapoptotic Bcl-xl gene that was upregulated in $\mathrm{CE}$ treated CEM cells but not in the type 1 HSB2 cells.

To confirm the results of the microarray analysis for Bcl$\mathrm{xl}$ and to further quantify Bcl-xl mRNA levels in GSI treated cells, we performed real time RT-PCR to assay Bclxl mRNA expression in all four cell lines after 3 (HSB2) or 4 (TALL1, CEM, and Jurkat J6) days of treatment with CE. As expected, compared to DMSO controls, the mRNA of the antiapoptotic gene Bcl-xl was upregulated in GSItreated CEM and Jurkat J6 cells, while it remained unchanged in GSI-treated TALL1 and HSB2 cells (Fig. 4a).

Finally, we analyzed Bcl-xl protein expression in CEtreated CEM and Jurkat J6 cells by Western blotting. Bcl-xl protein was reproducibly increased in both cell lines, although this effect was stronger in CEM than in Jurkat J6 (Fig. 4b). These results correspond to the mRNA expression of this gene and also to the different degrees by which GSI treatment inhibits the induction of apoptosis by chemotherapy in these cells. Bcl-xl belongs to the Bcl-2 family and is a functional and structural homolog of Bcl-2. Proteins of the Bcl-2 family are central regulators of

b

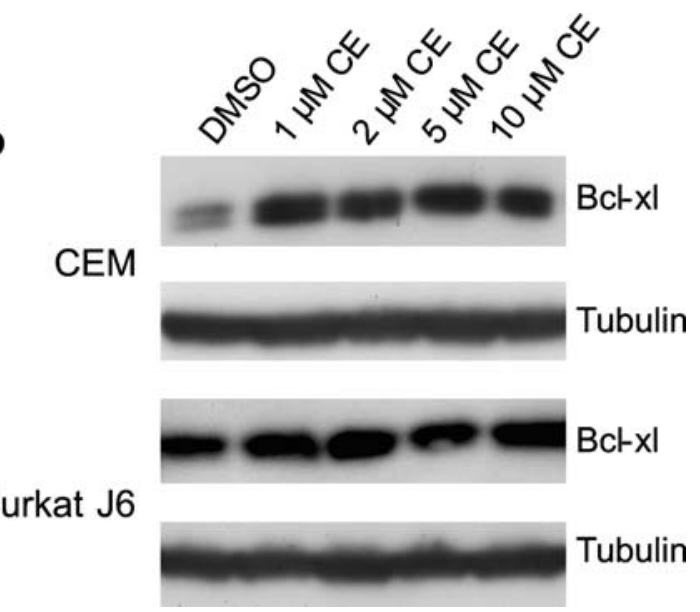

$( \pm \mathrm{SD})$ were calculated from three independent experiments. b Bcl-xl Western blot of CEM and Jurkat J6 cell lysates. Equal amounts of total protein were loaded. Tubulin was used as a loading control 
apoptosis and act primarily on the mitochondria. Bcl-xl functions as an antiapoptotic gene and provides protection against a wide variety of chemotherapeutic agents [19-21]. The increased expression of Bcl-xl in GSI-treated type 2 cells hence represents a candidate mechanism that represses drug-induced apoptosis.

\section{Discussion}

The role of the Notch1 pathway in the leukemogenesis of T-ALL $[1,7,8,11]$ and the high prevalence of activating Notch1 gene mutation in T-ALL $[9,10]$ has prompted the development of Notch1 pathway inhibition by $\gamma$-secretase inhibitors $[7,15,16]$ as an attractive novel therapeutic principle. It has been reasoned that this novel treatment strategy could be combined with standard chemotherapy to maximize the clinical effects [1].

However, the important finding of this study shows that the T-ALL cell response to combination of GSI treatment and chemotherapy is unpredictable. While some cell lines display the expected synergistic effects, in others, chemotherapyinduced apoptosis can actually be inhibited by GSI treatment. These unpredictable consequences of Notch activity are also reflected by diverse and context-dependent effects in other tissues. This is exemplified by the function of Notch that functions as an oncogene in T-cell leukemia [1, 22], lymphoma [23], and breast cancer [24, 25], whereas it acts as a tumor suppressor in skin [26] and small cell lung cancer [27]. Even in the same cell type, Notch activation can signal via different pathways $[28,29]$. In addition to the "classical" downstream targets such as Deltex [13], Hes1 and Hes5 [30, 31], Pre-T- $\alpha$ [31, 32], p21 [28, 33], important cancer-related downstream targets and signaling pathways including c-Myc $[12,34]$, NF-KB $[35,36]$, and PTEN/AKT-PI3K [37] have been identified more recently.

Although there are obvious limitations of extrapolating results obtained from an analysis of cell lines to the treatment of patients, the data reported here and previously by others [38] at least caution against the use of $\gamma$-secretase inhibition in T-ALL. Furthermore, gain-of-function mutations of Notch1 in T-ALL are associated with a particularly favorable treatment outcome at least in the context of Berlin-Frankfurt-Münster (BFM) protocols [10], which suggests that Notch 1 activity sensitizes T-ALL cells to chemotherapy. Considering the potential mechanism of the unfavorable effect of GSI treatment on the activity of chemotherapy in type 2 cells, we identified the induction of the antiapoptotic gene Bcl-xl by GSI as a plausible candidate. However, despite the confirmed downregulation of Deltex 1 mRNA as a bona fide Notch1 target, it is an open question whether the induction of Bcl-xl is caused by an inhibition of the Notch1 pathway in type 2 cells, because $\gamma$-secretase inhibition is not specific for Notch1 processing. However, irrespective of the exact GSI-triggered mechanism that can inhibit the induction of apoptosis by chemotherapy, the data reported here indicate that the effects of GSI treatment will have to be comprehensively evaluated in preclinical models before it can be used in clinical trials.

Acknowledgments This work was supported by a grant from the German Federal Ministry of Education and Research (NGFNplus) and by generous support by "Tour der Hoffnung".

\section{References}

1. Grabher C, von Boehmer H, Look AT (2006) Notch1 activation in the molecular pathogenesis of T-cell acute lymphoblastic leukaemia. Nat Rev Cancer 6:347-359. doi:10.1038/nrc1880

2. Pui CH, Schrappe M, Ribeiro RC, Niemeyer CM (2004) Childhood and adolescent lymphoid and myeloid leukemia. Hematology 123-130

3. Herold R, von Stackelberg A, Hartmann R, Eisenreich B, Henze G (2004) Acute lymphoblastic leukemia-relapse study of the Berlin-Frankfurt-Munster group (ALL-REZ BFM) experience: early treatment intensity makes the difference. J Clin Oncol 22:569-570. doi:10.1200/JCO.2004.99.153

4. Schrappe M, Reiter A, Zimmermann M, Harbott J, Ludwig WD, Henze G, Gadner H, Odewald E, Riehm H (2000) Long-term results of four consecutive trials in childhood ALL performed by the ALL-BFM study group from 1981 to 1995 . Berlin-FrankfurtMunster. Leukemia 14:2205-2222. doi:10.1038/sj.leu.2401973

5. Ellisen LW, Bird J, West DC, Soreng AL, Reynolds TC, Smith SD, Sklar J (1991) TAN-1, the human homolog of the Drosophila Notch gene, is broken by chromosomal translocations in T lymphoblastic neoplasms. Cell 66:649-661. doi:10.1016/0092-8674(91)90111-B

6. Pear WS, Aster JC, Scott ML, Hasserjian RP, Soffer B, Sklar J, Baltimore D (1996) Exclusive development of T cell neoplasms in mice transplanted with bone marrow expressing activated Notch alleles. J Exp Med 183:2283-2291. doi:10.1084/jem.183.5.2283

7. Weng AP, Nam Y, Wolfe MS, Pear WS, Griffin JD, Blacklow SC, Aster JC (2003) Growth suppression of pre-T acute lymphoblastic leukemia cells by inhibition of Notch signaling. Mol Cell Biol 23:655-664. doi:10.1128/MCB.23.2.655-664.2003

8. Allman D, Punt JA, Izon DJ, Aster JC, Pear WS (2002) An invitation to $\mathrm{T}$ and more: Notch signaling in lymphopoiesis. Cell 109:S1-S11. doi:10.1016/S0092-8674(02)00689-X

9. Weng AP, Ferrando AA, Lee W, Morris JP 4th, Silverman LB, Sanchez-Irizarry C, Blacklow SC, Look AT, Aster JC (2004) Activating mutations of Notch 1 in human $\mathrm{T}$ cell acute lymphoblastic leukemia. Science 306:269-271. doi:10.1126/ science. 1102160

10. Breit S, Stanulla M, Flohr T, Schrappe M, Ludwig WD, Tolle G, Happich M, Muckenthaler MU, Kulozik AE (2006) Activating NOTCH1 mutations predict favorable early treatment response and long-term outcome in childhood precursor T-cell lymphoblastic leukemia. Blood 108:1151-1157. doi:10.1182/blood-2005-124956

11. Pear WS, Aster JC (2004) T cell acute lymphoblastic leukemia/ lymphoma: a human cancer commonly associated with aberrant Notch1 signaling. Curr Opin Hematol 11:426-433. doi:10.1097/ 01.moh.0000143965.90813.70

12. Weng AP, Millholland JM, Yashiro-Ohtani Y, Arcangeli ML, Lau A, Wai C, Del Bianco C, Rodriguez CG, Sai H, Tobias J, Li Y, Wolfe 
MS et al (2006) c-Myc is an important direct target of Notch1 in Tcell acute lymphoblastic leukemia/lymphoma. Genes Dev 20:20962109. doi:10.1101/gad.1450406

13. Deftos ML, He YW, Ojala EW, Bevan MJ (1998) Correlating Notch signaling with thymocyte maturation. Immunity 9:777-786. doi:10.1016/S1074-7613(00)80643-3

14. Miele L (2006) Notch signaling. Clin Cancer Res 12:1074-1079. doi:10.1158/1078-0432.CCR-05-2570

15. Shih IM, Wang TL (2007) Notch signaling, gamma-secretase inhibitors, and cancer therapy. Cancer Res 67:1879-1882. doi:10.1158/0008-5472.CAN-06-3958

16. Lewis HD, Leveridge M, Strack PR, Haldon CD, O'neil J, Kim H, Madin A, Hannam JC, Look AT, Kohl N, Draetta G, Harrison T et al (2007) Apoptosis in T cell acute lymphoblastic leukemia cells after cell cycle arrest induced by pharmacological inhibition of Notch signaling. Chem Biol 14:209-219. doi:10.1016/j. chembiol.2006.12.010

17. Armstrong SA, Look AT (2005) Molecular genetics of acute lymphoblastic leukemia. J Clin Oncol 23:6306-6015. doi:10.1200/JCO.2005.05.047

18. Viegas MH, Gehring NH, Breit S, Hentze MW, Kulozik AE (2007) The abundance of RNPS1, a protein component of the exon junction complex, can determine the 5 variability in efficiency of the Nonsense Mediated Decay pathway. Nucleic Acids Res 35:4542-4551. doi:10.1093/nar/gkm461

19. Kaufmann SH, Vaux DL (2003) Alterations in the apoptotic machinery and their potential role in anticancer drug resistance. Oncogene 22:7414-7430. doi:10.1038/sj.onc.1206945

20. Cory S, Adams JM (2002) The Bcl-2 family: regulators of the cellular life-or-death switch. Nat Rev Cancer 2:647-656. doi: $10.1038 / \mathrm{nrc} 883$

21. Chan SL, Yu VC (2004) Proteins of the Bcl-2 family in apoptosis signalling: from mechanistic insights to therapeutic opportunities. Clin Exp Pharmacol Physiol 31:119-128. doi:10.1111/j.14401681.2004.03975.x

22. Aster JC, Pear WS (2001) Notch signaling in leukemia. Curr Opin Hematol 8:237-244. doi:10.1097/00062752-20010700000010

23. Jundt F, Anagnostopoulos I, Förster R (2002) Activated Notch1 signaling promotes tumor cell proliferation and survival in Hodgkin and anaplastic large cell lymphoma. Blood 99:33983403. doi:10.1182/blood.V99.9.3398

24. Politi K, Feirt N, Kitajewski J (2004) Notch in mammary gland development and breast cancer. Semin Cancer Biol 14:341-347. doi:10.1016/j.semcancer.2004.04.013

25. Stylianou S, Clarke RB, Brennan K (2006) Aberrant activation of Notch signaling in human breast cancer. Cancer Res 66:15171525. doi:10.1158/0008-5472.CAN-05-3054

26. Nicolas M, Wolfer A, Raj K, Kummer JA, Mill P, van Noort M, Hui CC, Clevers H, Dotto GP, Radtke F (2003) Notch1 functions as a tumor suppressor in mouse skin. Nat Genet 33:416-421. doi:10.1038/ng1099
27. Sriuranpong V, Borges MW, Ravi RK, Arnold DR, Nelkin BD, Baylin SB, Ball DW (2001) Notch signaling induces cell cycle arrest in small cell lung cancer cells. Cancer Res 61:3200-3205

28. Rangarajan A, Talora C, Okuyama R, Nicolas M, Mammucari C, Oh H, Aster JC, Krishna S, Metzger D, Chambon P, Miele L, Aguet $\mathrm{M}$ et al (2001) Notch signaling is a direct determinant of keratinocyte growth arrest and entry into differentiation. EMBO J 20:3427-3436. doi:10.1093/emboj/20.13.3427

29. Jang MS, Miao H, Carlesso N, Shelly L, Zlobin A, Darack N, Qin JZ, Nickoloff BJ, Miele L (2004) Notch-1 regulates cell death independently of differentiation in murine erythroleukemia cells through multiple apoptosis and cell cycle pathways. J Cell Physiol 199:418-433. doi:10.1002/jcp.10467

30. Nishimura M, Isaka F, Ishibashi M, Tomita K, Tsuda H, Nakanishi S, Kageyama R (1998) Structure, chromosomal locus, and promoter of mouse Hes2 gene, a homologue of Drosophila hairy and Enhancer of split. Genomics 49:69-75. doi:10.1006/geno.1998.5213

31. Deftos ML, Huang E, Ojala EW, Forbush KA, Bevan MJ (2000) Notch1 signaling promotes the maturation of CD4 and CD8 SP thymocytes. Immunity 13:73-84. doi:10.1016/S1074-7613(00) 00009-1

32. Reizis B, Leder P (2002) Direct induction of T lymphocytespecific gene expression by the mammalian Notch signaling pathway. Genes Dev 16:295-300. doi:10.1101/gad.960702

33. Devgan V, Mammucari C, Millar SE, Brisken C, Dotto GP (2005) $\mathrm{p} 21 \mathrm{Waf} 1 / \mathrm{Cip} 1$ is a negative transcriptional regulator of Wnt4 expression downstream of Notch1 activation. Genes Dev 19:1485-1495. doi:10.1101/gad.341405

34. Klinakis A, Szabolcs M, Politi K, Kiaris H, Artavanis-Tsakonas S, Efstratiadis A (2006) Myc is a Notch1 transcriptional target and a requisite for Notch1-induced mammary tumorigenesis in mice. Proc Natl Acad Sci USA 103:9262-9267. doi:10.1073/pnas.0603371103

35. Shin HM, Minter LM, Cho OH, Gottipati S, Fauq AH, Golde TE, Sonenshein GE, Osborne BA (2006) Notch1 augments NFkappaB activity by facilitating its nuclear retention. EMBO J 25:129-138. doi:10.1038/sj.emboj.7600902

36. Vilimas T, Mascarenhas J, Palomero T, Mandal M, Buonamici S, Meng F, Thompson B, Spaulding C, Macaroun S, Alegre ML, Kee BL, Ferrando A et al (2007) Targeting the NF-kappaB signaling pathway in Notch1-induced T-cell leukemia. Nat Med 13:70-77. doi: $10.1038 / \mathrm{nm} 1524$

37. Palomero T, Sulis ML, Cortina M, Real PJ, Barnes K, Ciofani M, Caparros E, Buteau J, Brown K, Perkins SL, Bhagat G, Agarwal AM et al (2007) Mutational loss of PTEN induces resistance to NOTCH1 inhibition in T-cell leukemia. Nat Med 13:1203-1210. doi:10.1038/nm1636

38. De Keersmaecker K, Lahortiga I, Mentens N, Folens C, Van Neste L, Bekaert S, Vandenberghe P, Odero MD, Marynen P, Cools J (2008) In vitro validation of $\gamma$-secretase inhibitors alone or in combination with other anti-cancer drugs for the treatment of $\mathrm{T}$ cell acute lymphoblastic leukemia. Haematologica 93:533-542. doi:10.3324/haematol.11894 